\title{
Groundwater Recharge through Infiltration Process: A Case Study of Umudike, Southeastern Nigeria
}

\author{
Magnus U. Igboekwe*, Adindu Ruth \\ Department of Physics, Micheal Okpara University of Agriculture, Umuahia, Nigeria \\ E-mail:igboekwemu@yahoo.com \\ Received January 1, 2011; revised February 3, 2011; accepted April 2, 2011
}

\begin{abstract}
Although water is a renewable resource for sustaining life and environment, excessive pumping of groundwater results in the ground water table being depleted. The major natural source of groundwater recharge is rainfall. In Umudike just like many other areas, the rate of natural recharge is lower than pumping rate. This is due to increasing economic and agricultural activities and also urbanization. Over exploitation of groundwater is a threat to the water quality and table and creates hydrological imbalance. This imbalance includes degradation in hydrological and hydro-chemical characteristics of the aquifer. Artificial recharge of water table aquifers becomes necessary to improve the hydrodynamic conditions of groundwater. A drop in piezometric level can be remedied by artificial recharge of groundwater through infiltration process using water from dams, lakes, rivers, runoff and sewage effluent. Results of water table survey conducted at Umudike show that it peaks at $85 \mathrm{~m}$ (above sea level) before recharge and $95 \mathrm{~m}$ after recharge. The recharge of groundwater is basically through rainfall and river water.
\end{abstract}

Keywords: Artificial Recharge, Umudike, Infiltration, Water Table

\section{Introduction}

Artificial Recharge of aquifers is devised as a means of increasing groundwater resources. Regulating surface flow, providing underground storage of water and avoiding its loss in seas or in salt depressions, also help to preserve the recharged groundwater. A number of water table aquifers in coastal zones are being increasingly exploited and affected [1,2]. Artificial recharge of groundwater can be used to preserve the water resources and restore the water table aquifer which has been threatened due to overexploitation and a fall in piezometric level. [3].

Artificial Recharge has been used in many countries for protecting against predicted water shortages.

For example in India, a sustainable technology has been developed, which consist of runoff from rooftop through PVC pipe, passed through a filter and finally put into an aquifer formation above water table via a recharge well. In Tunisia, a pilot programme to mobilize resources, aimed at stormy water form winter rains, which would be used during the dry season, was developed [4]. The objective of artificial recharge is to recreate a piezometric level of groundwater that is either higher than or equal to the normal, with a better quality of aquifer water. The objectives of groundwater recharge have been defined by Asono \& Contruvo, [5]; Bouwer \& Pyne [6] and Grunheid [7]. Artificial recharge used in many countries has a clear correlation between the fluctuations of water table and the recharge rate by irrigation. Also extremely large amount of water is continuously added to the soil during sprinkling infiltrations. It alters the flow of water and nutrients in the soil, resulting in an increase in $\mathrm{pH}$. and base cation concentration of the uppermost soil layers and changes in nitrogen cycle. Another study conducted in France along Seine River recorded a total elimination of parasite between raw water used for the artificial recharge and the water in the aquifer [8].

\subsection{Location}

Umudike is found in Ikwuano Local Government Area of Abia State in the south east zone of Nigeria. It is located between latitude $5^{\circ} 19^{\prime} \mathrm{N}$ and $5^{\circ} 30^{\prime} \mathrm{N}$ and between longitude $7^{\circ} 30^{\prime} \mathrm{E}$ and $7^{\circ} 37^{\prime} \mathrm{E}$. It is within the Kwa Ibo River watershed which has Anya River as the major tributary. The latter is found within the premises of Michael Okpara University of Agriculture, Umudike and 
flows across the National Root Crops Research Institute, Umudike, see Figure 1.

\subsection{Geology of Umudike}

The geologic formation of Umudike is that of Coastal Plain Sands, also known as the Benin Formation. It belongs to the later Tertiary to Early Quaternary. The Formation is about $200 \mathrm{~m}$ thick at Umudike. The lithology is unconsolidated fine-medium-coarse grained crossbedded sands occasionally pebbly with localized clay and shale that favors aquifer formation.

\subsection{Piezometric Cycle}

The piezometric Cycle of the study area shows a cycle of 3 phases which corresponds to the rainy (wet) season, when it enjoys a steady heavy rainfall period of 3 months from May to July; a short break period of dry weather, and a return of another copious rainfall. There are two peak months of rainfall in a year: July and September. The mean monthly rainfall during the wet season is $335 \mathrm{~mm}$, which falls to $65 \mathrm{~mm}$ during the dry season that lasts from October to April [9]. The Anya River, which is the main tributary of Kwa Ibo River, enjoys reasonable volume of water during these rainfall peaks. This River serves as water resource for the recharge of the aquifer in the study area.

\subsection{Hydrology}

The Benin Formation or the Coastal Plain Sands has high aquifer permeability. The permeability of the study area is about $3.15 \mathrm{~m} /$ day. Groundwater recharge due to rainfall takes place from the top layer. In the normal course, the surface water goes to the ground water by natural infiltration process after crossing different layers of clay and fine sands. The top layer consists of $5-120 \mathrm{~m}$ topsoil/laterite underlain by a sandy zone, 68 - $320 \mathrm{~m}$ thick. There is a serious groundwater abstraction owing to the presence of Michael Okpara University of Agriculture, Umudike (MOUAU) and the National Root Crops Research Institute. Abstraction is through wells and groundwater pumping. The pumping rate varies from $100 \mathrm{~m}^{3} \cdot \mathrm{day}^{-1}$ to $150 \mathrm{~m}^{3} \cdot$ day $^{-1}$.

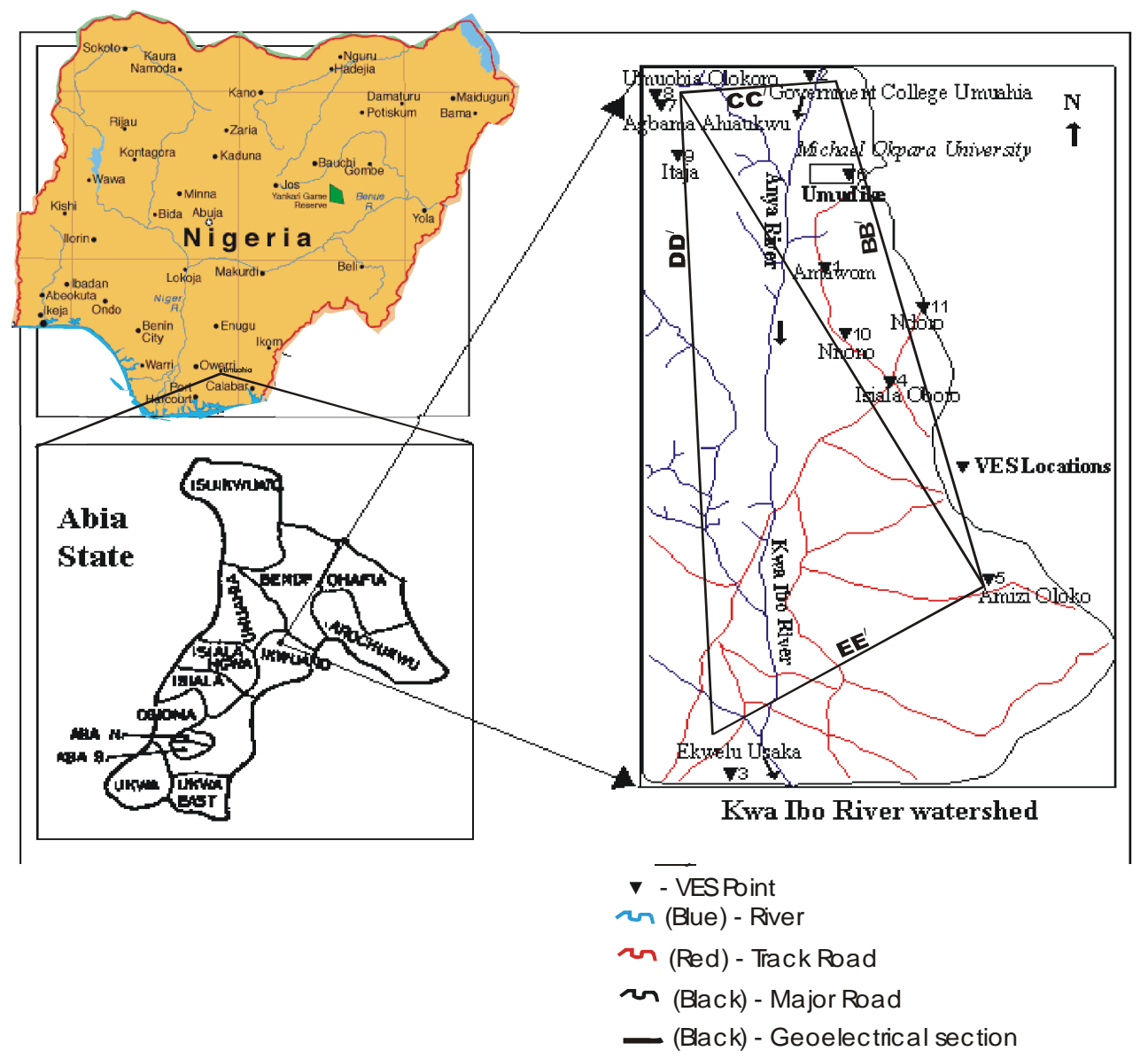

Figure 1. Location map of Kwa Ibo River watershed, showing Umudike (Adapted from Igboekwe et al., 2006). 


\section{Methodology}

The depth of bore-hole is an important parameter that governs the rate of recharge of groundwater. The bore hole log data is therefore found to be of great importance in deciding the optimum depth of recharge and hence the boring equipment required. The bore log data of BH No. 3 at Michael Okpara University of Agriculture, Umudike indicates that a minimum of $45 \mathrm{~m}$ in depth is required to reach the first aquifer consisting of medium sands, and about $82 \mathrm{~m}-88 \mathrm{~m}$ for the second aquifer. The groundwater contour map in Figure 2 clearly shows this. Alternatively, the subsurface hydrological data can also be used in deciding the optimum depth of recharge. It is also essential to have a good permeability that can be obtained by going deep enough to encounter medium sands or coarse sand strata.

To stop the groundwater depletion, the rain and surplus water from the Anya River was stored by artificial recharging. The Artificial recharge system consists of

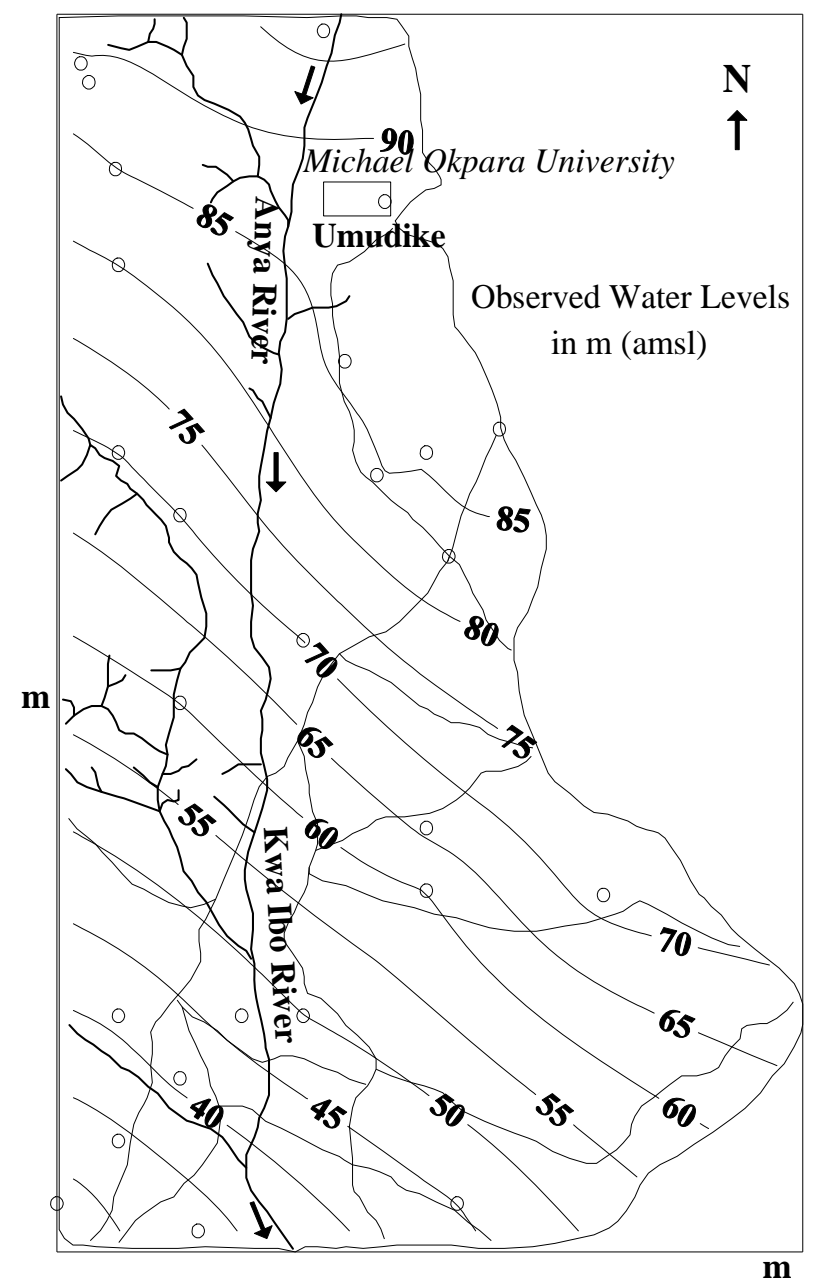

Figure 2.Water level contour map of Umudike in Kwa Ibo River watershed (adapted from Igboekwe et al., 2008). injecting water into the underlying water bearing aquifer. Two recharging systems were constructed by the sides of the drain, one at the University, (MOUAU) and the other at the center of the village near Amawom. Following the design of Radhey Mohan et al. [10]; see Figure 3, a recharge well of about $3.0 \mathrm{~m} \times 9.0 \mathrm{~m}$ were constructed by the side of the drain. It has about $0.5 \mathrm{~m}$ thick layer of fine sand, $0.5 \mathrm{~m}$ thick layer of coarse sand and 0.5 thick layer of $5-12 \mathrm{~mm}$ gravel. A borehole of about $50 \mathrm{~m}$ deep; $0.5 \mathrm{~m}$ diameter was drilled with the rig machine by direct mud circulation process. A P.V.C pipe of diameter $0.3 \mathrm{~m}$ length was lowered in the borehole, and the space between the pipe and the borehole was filled with 5-12 mm of gravel. The length of the perforated part of the pipe in the coarse grained sands was about $20 \mathrm{~m}$, from the aquifer. Piezometers made of PVC pipes were installed by the sides of the drain so that the water level reading before and after recharge could be taken. Observations were also taken from about 6 abstraction wells within the catchments area located at about a distance of $500-600 \mathrm{~m}$ away from each other and about 1000 to $2000 \mathrm{~m}$ away from the recharge well.

\section{Results}

The rise of the water level was seen to be more at some locations where it was initially low, especially during the peak periods of the rainy season, i.e. July and September. During the recharge process, the average depth of groundwater rose up to $35 \mathrm{~m}$ for the first aquifer within the charging catchments area instead of the usual $45 \mathrm{~m}$ depth. The maximum rise of water table was observed to be in abstraction wells located southwards in the direction of the river flow e.g. at the Engineering Department of MOUAU. This is located at about $1 \mathrm{~km}$ away from the recharging well. The direction of the velocity field vector at these sites is from North to South. Runoff is low while recharge is here. The maximum rise shows that the groundwater table depends on the type of strata. Water analysis carried out at MOUAU by Ebilah et al. [11], indicates good quality water which compares well with the WHO standards except for the $\mathrm{pH}$ of 5 which of course is not detrimental to health. Hence there is no need for treatment or sedimentation of raw water of the drain. Table 1 shows that water increases due to recharge of the underground water at closer locations than at farther points. At Umudike it is $85 \mathrm{~m}$ (above sea level) before recharge and $95 \mathrm{~m}$ after recharge (Figure 2). This is due to infiltration of underground water by rainfall and river water.

\section{Conclusions}

Groundwater recharge is a function of the annual average 


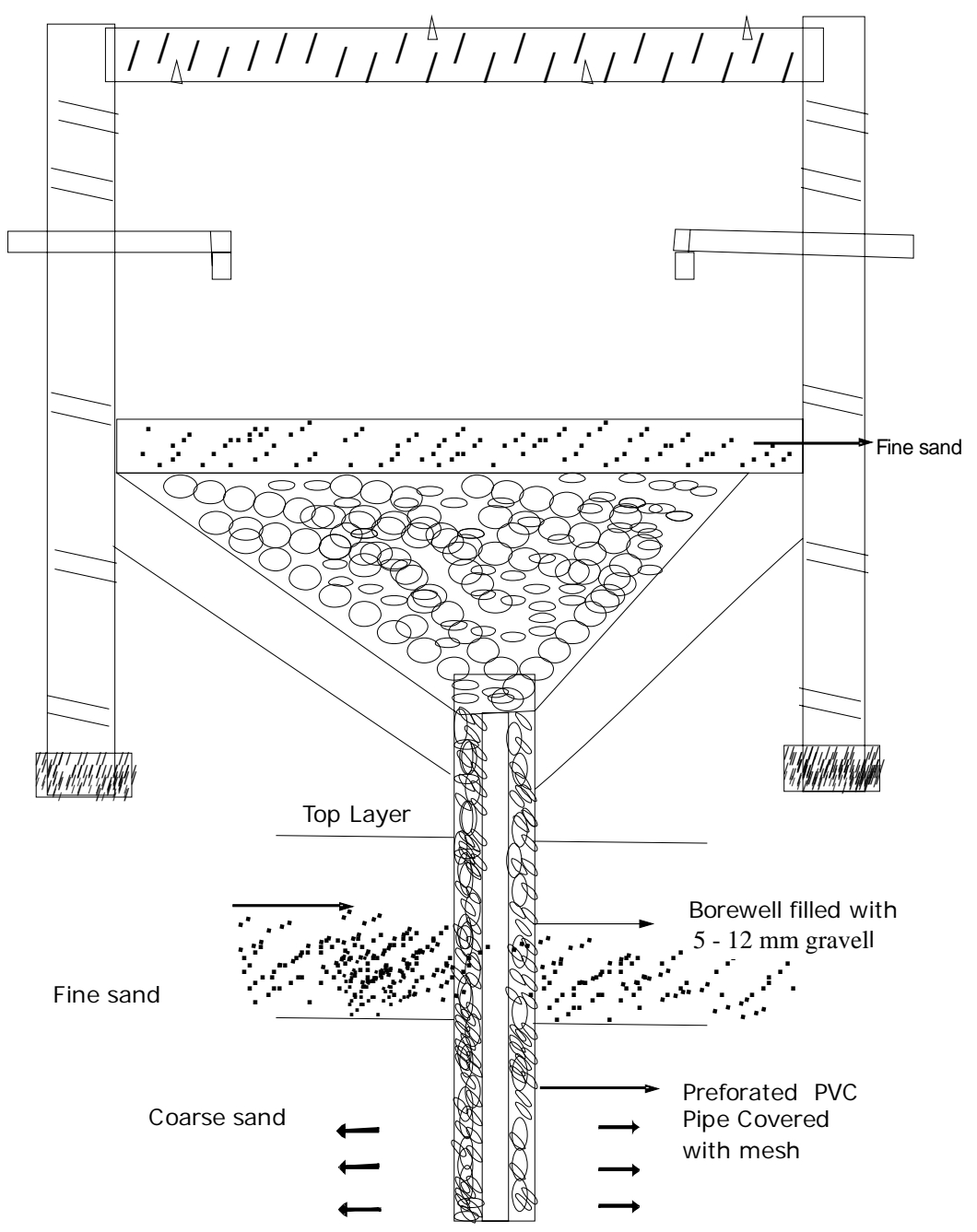

Figure 3. Schematic of recharge arrangement with a bore well.

Table 1. Depth of water table (amsl).

\begin{tabular}{clcc}
\hline S/N & \multicolumn{1}{c}{ Location } & $\begin{array}{c}\text { Water Table } \\
\text { before recharge (m) }\end{array}$ & $\begin{array}{c}\text { Water Table after recharge } \\
(\mathbf{m})\end{array}$ \\
\hline 1 & Engineering Dept, MOUAU 1 km from recharge well. & 85 & 95 \\
2 & From Vice Chancellor's lodge. 1.5 km from recharge well. & 80 & 88 \\
3 & Observation well at Research Institute 1.7 km from recharge well. & 83 & 87 \\
4 & Village open well located at 2 km from recharge well. & 83 & 87 \\
5 & Bore holes at Amawon 1 km from the recharge well. & 79 & 85 \\
6 & Open well at Amawon 1.5 km away from recharge well. & 79 & 83 \\
\hline
\end{tabular}

rainfall, hydrological characteristics, geology of the area, slopes, and nature of the soil. Increase in rainfall leads to increase in groundwater level. Conversely, decrease in rainfall leads to groundwater depletion. Over exploitation in the form of excessive pumping to meet the increasing water demands was observed in the study area. The geo- logy of Umudike supports to a reasonable extent, the natural infiltration process especially during the rainy season. Artificial recharge yields good promising results when applied. With the rate of recharge recorded, Umudike looks very promising for groundwater development programme in Nigeria. 


\section{References}

[1] G. Demarsily, "Importance of the Maintenance of Temporary Ponds in Arid Climates for the Recharge of Groundwater," Comptes Rendus Geosciences, Vol. 335, No. 13, 2003, pp. 933-934. doi:10.1016/j.crte.2003.10.001

[2] Fedrigoni, “Origin de la Mineralization et Comportment Hydrogèochimique d' une Nappe Phrèatigue Soumise à des Contraintes Naturelles et Anthropigues Sevèré: Example de la Nappe de Djebenia (Tunisie)," Earth and Planetary Science Letters, Vol. 332, 2001, pp. 665-671.

[3] P. Nöjd, et al., “Artificial Recharge of Groundwater through Sprinkling Infiltration: Impacts on Forest Soil and the Nutrients Status and Growth of Scots Pine," Science of the Total Environment, Vol. 407, No. 10, 2009, pp. 3365-3371. doi:10.1016/j.scitotenv.2009.01.062

[4] Ministère de L' Agriculture, "Rapport sur l' etat des Nappes Phrèatigues et Profondes de la Tunisie,” Ministère de l’ Agriculture, Tunis, 1996.

[5] T. Asono and J. A. Cotruvo, "Groundwater Recharge with Reclaimed Municipal Waste Water: Health and Regulatory Consideration,” Water Research, Vol. 38, No. 8, 2004, pp. 1941-1951. doi:10.1016/j.watres.2004.01.023

[6] H. Bouwer and R. D. G. Pyne, "Artificial Recharge of Groundwater,” National Groundwater Association, Baltimore, 2005.
[7] S. Grünheid, et al., "Removal of Bulk Dissolved Organic Carbon (DOC) and Trace Organic Compounds by Bank Filtration and Artificial Recharge," Water Research, Vol. 39, No. 14, 2005, pp. 3219-3228. doi:10.1016/j.watres.2005.05.030

[8] M. Detay and J. C. Bersillion, "La Realimentation Artificielle de Nappes Profondes. Faisabilite et Consequences,” La Houille Branched, Vol. 366, 1996, pp. 57-61. doi:10.1051/lhb/1996040

[9] M. U. Igboekwe, E. E. Okwueze and C. E. Okereke, “Delineantion of Potential Aquifer Zones from Geoelectric Soundings in Kwa Ibo River Watershed, South Eastern Nigeria,” Journal of Engineering and Applied Sciences, Vol. 1, No. 4, 2006, pp. 410-421.

[10] M. Radhey, “Artificial Recharging of Groundwater from Rain and Surplus Canal Water along Harsauli Drain, District," Proceedings of ISWRPM 2003, Muzaffarnagar, 11-12 October 2003.

[11] Ebilah-Salmon and Partners, "Investigation of the Existing Water Supply Facilities within the University Complex," Geophysical Report and Recommendations for Reactivation and Future Exploitation for Potable Water Supply, Federal University of Agriculture, Umudike, 1994, p. 25. 